\title{
Prospect for Cell Phones as Instructional Tools in the EFL Classroom: A Case Study of Jahangirnagar University, Bangladesh
}

\author{
Roksana Begum \\ Department of English, Jahangirnagar University, Dhaka 1342, Bangladesh \\ E-mail: rbegum91@yahoo.com
}

\begin{abstract}
The aim of this study was to investigate the potentiality of cell phone use in the EFL classroom of Bangladesh as an instructional tool. The researcher conducted a case study on Jahangirnagar University of Bangladesh. For the study, some SMS based class tests were conducted in the English Department of the university where one hundred undergraduate EFL students participated as subjects. Before the tests, Some EFL teachers sent mobile SMS to students as a means of instruction for teaching appropriate use of preposition for one week. After one week, the teachers took some class tests where the test questions were delivered via SMS and the students also answered the test questions by mobile SMS. The author collected data through students' questionnaires, and teachers' interview records and classroom observation reports. The research results demonstrated that cell phone has great potential as an instructional tool despite some challenges that can be resolved by the sincere attempts of the authority, teachers and by changing the ethical point of view that consider cell phones as mere a disturbing factor in the classroom.
\end{abstract}

Keywords: EFL, Classroom teaching, SMS, Mobile phone, E-learning and M-learning, Bangladesh

\section{Introduction}

Learning English is very important in the non-English speaking countries as it is the only medium through which the access to modern developed world becomes possible. However, developing modern technological support for effective EFL learning is a critical issue in the developing countries like Bangladesh. With the rapid growth of wireless and mobile learning technology, the use of mobile phone and other portable devices are now beginning to have an impact on language teaching and learning throughout the world. Similarly, the development of language learning technologies recently has tended to be mobilized, portable, and personalized. These trends have led to learning forms changing from traditional classroom learning to electronic learning (E-learning), mobile learning (M-learning) or ubiquitous learning (U-learning). Among these noble learning forms, mobile learning is effective and flexible; that is, mobile learning can overcome restrictions of time and space, enabling learners to study whenever and wherever possible (Chen and Chung, 2007) As access to wireless networks expands and ownership of devices that can communicate with such networks increases, the use of mobile devices to support language learning becomes ever more common (Kukulska-Hulme and Shield, 2008). However, many studies have attempted to improve the language learning and teaching using mobile devices such as mobile phones, MP3/MP4 players, PDAs and palmtop and computer. Moreover, the previous researches developed the idea that, Mobile Assisted Language Learning is very much significant for the development of pedagogical sector. Still, one aspect, the efficacy of cell phones as language learning tool in the undergraduate EFL classroom, remains rare. Whether the present pedagogical condition of Bangladesh supports cell phone or smart phone as a language learning tool or not, is really a considerable matter. The current study focuses on the use of mobile phone or cell phone in undergraduate EFL classroom as an instructional tool in the context of Bangladesh.

\subsection{What is Mobile Based Language Learning (MALL)?}

Mobile Assisted Language Learning (MALL) describes an approach to language learning that is enhanced through use of a mobile device. MALL is a subset of both Mobile Learning (m-learning) and Computer-assisted language learning (CALL). MALL is involved with the use of the mobile technologies, such as mobiles phones, MP3 /MP4 players, PDAs and palmtop computers, to support students' language learning. With MALL students are able to access language learning materials, and to communicate with their teachers and peers, at anytime, anywhere (Kukulska-Hulme, 2006).MALL currently provides the utilization and retention of newly acquired language skills as well as primary source of language education for EFL students to acquire one or more new languages. Klopfer et al. (2002) claimed five properties of mobile devices which can produce educational benefits. Those are

1) Portability2) Social interactivity3) Context sensitivity.4) Connectivity5) Individuality

\subsection{Applications of cell phones in the EFL classroom}

The increasing mobile subscribers in the world that is almost one million new user everyday and eleven new users 
every second, refers the acceptance of the mobile phones throughout the world. But it is little bit neglected in the pedagogical sector. But, Cell phones are so advanced and smart that they actually perform almost the same functions and features as personal computers (Cui and Wang, 2008) and like all communication and computing devices, cell phones, can be used to learn (Prensky, 2004). The language learning activities through cell phones are also internationally accepted. Cell phones with wireless Internet access offer a world of possibilities for classroom instruction. With the great development of cell phone functions and features now teachers can also realize the instructional potential of cell phones in EFL classroom. But the problem is they don't know how to implement classroom activities by using cell phone devices for language teaching. Here, some possible strategies to use the cell phone in the EFL classroom are presented for the teachers and students.

- Downloading required e-books, software and dictionaries from mobile Internet for reading practice

- Using the on line dictionaries for looking through word meaning.

- Using translation dictionaries for definition of a word.

- Capturing class notes by the means of mobile camera

- Developing reading and speaking skill through the recorded short stories.

- $\quad$ Practising pronunciation by recording audio materials

- Receiving text messages from teachers with class content

- Sending SMS in short and crispy sentence for grammar practice and teacher can later do correction by SMS reply.

- $\quad$ Students can get feedback from teachers via SMS. Homework and some tests can also be delivered in this

way.

- $\quad$ Snapping pictures through cell phone camera for assignment, field trips and reports.

- Doing research through the use of text message and Internet browser

- $\quad$ Recording students speech in cell phone voice recorder options and later use it for speaking and pronunciation tests (Thornton and Houser, 2004)

- $\quad$ For learning key language or grammar through listening enjoyable songs in mobile i pod.

- Using sound effects as stimulus for writing.

- Voice threading; people can use their cell phones to call and record their voices to communicate with others or post their comments to their Voice Thread page (Cui and Wang, 2008)

- Using mobile games to develop problem solving and critical thinking skill.

- Using word match games as the means of spelling practice.

1.3 Why mobile based language learning is potential in Bangladesh?

Bangladesh is one of the world's least developed countries with a vast population. Whereas the developed countries like USA, Japan, and Australia are now using a variety of technology to provide learning and train the teachers, e-learning and m-learning are truly absent in Bangladesh. Very few Universities support e-learning, only few years ago one university took initiative to conduct e-learning. For lack of electricity and skilled teacher e-learning environment cannot be established in Bangladesh. Computer and Internet service has also been expanded after 1996.It is also hardly possible for individual student to provide a PC. Against all these odds, the expansion of mobile service deserves mention because of the rapid growth of mobile users in this decade. In 2005, the numbers of mobile users were about eleven million which is now reaching at about fifty millions. Within a very short time the number of mobile users expanded though the users of Internet remains low. Even a day laborer can afford a mobile for its cheap call rate and SMS service. The country is connected to information and communication, at a large extent, by the increasing expansion of mobile use. In despite of being a least developed country, it has created a booming mobile market. Moreover, the students are frequent users of mobile phone and familiar with the mobile devices; this is true for the students of both urban and rural places. Accordingly, it will be plausible to use mobile phone as a tool for learning especially for language learning

Indeed, it has been suggested that the total cost of ownership of new mobile technologies may be significantly below the running costs of refurbished computer suites given 'free' by donors (Power, 2006). At the current time, most mobile phones in use in Bangladesh are very though not so modern, have the capacities like SMS, voice mail, recorders, still-cameras, videos, games. However, most of the phones now being sold support audio and music 
playback, have color screens, and are capable of accessing the Internet and email (Power and Shrestha, 2009).Language students use the mobile phone in their daily life - both as students and as ordinary citizens (Chen, 2007). They use their cell phones usually for communicating with the parents, friends and teachers and recreation purposes rather than learning English. They also do SMS, take photos, enjoy music, play games and can browse the Internet because of the cheap rate of Internet connection by some mobile operators. This Internet connection in a mobile phone offer fantastic opportunities to use the handset as a tool to learn foreign language. With the growth of mobile users, the mobile phone companies also design new and updated cell phones installing a number of functions such as SMS, games, GPS, audio, video, recorder, wireless Internet, TV display etc. Compared with other developing countries, the cell phone users of Bangladesh did not properly explore the functions of cell phones as instructional tools in foreign language classroom. Powerful features and functions of mobile devices offer cell phone users such as teachers and instructional designers great potential and feasibility for educational use, especially in the mobile learning, which will give people from diverse fields a new way to learn.(Cui and Wang, 2008).

Although Bangladesh is a few steps away from adopting mobile as a tool of second language learning, recently with the aim of teaching language to six million people of Bangladesh, a mobile-based language learning program has been launched by a charity arm of the BBC. The program was named as 'Janala' where English is taught through the use of Internet and fast growing mobile technology. It has gradually achieved a great popularity among the people because of the easy access to it via six mobile operators whose network covers almost the entire population. The poplarity of this teaching program bears out the acceptance of mobile phones as a language learning tool by mass people. Considering the educational value of cell phone devices the future potentiality of cell phone as instructional tools can also be predicted

\section{Literature review}

In the last half a decade, researchers' attention has been drawn to both mLearning for language study, and to using SMS for learning generally (Li, 2009).Among them some previous studies suggested the feasibility and usability of mobile SMS for learning English. For example, Song \& Fox (2005) reported on a study that explored the role of mobile Short Message Service (SMS) in English as second language (ESL) vocabulary learning for working adult learners. The study findings suggested that mobile technology improved the learners' performance in their learning. Market et al. (2006) explored use of SMS to encourage classroom interactions. In their research some students sent SMS via their personal cell phones and these SMS were exposed on the screen of a laptop where a modem interfacing with customized software was used to produce SMS file in order to view the sent messages. The teacher then replied verbally and this message with teacher's verbal reply was later posted online to promote interactivity by further comments. An important usage of cell phones in L2 classroom is capturing SMS into database that is displayed on a message board. Teachers can use computers to send SMS to students, with particular advantage for administrative purposes (Meurant, 2007). So (2009) presented an underlying technology of using GSM modems to build the SMS based teaching and learning system. The system is capable of supporting administrative, teaching and learning activities such as brainstorming, voting, and assessment via the SMS technology. Li (2009) undertook an action research to investigate how short message (SMS) assisted English as a Second Language (ESL) student' vocabulary learning as well as investigating students' acceptance and usage of it. The study results revealed that SMS based vocabulary learning was able to enhance ESL students learning by adding flexibility and providing a stronger motivation for study. One study conducted in Bangladesh by Alam and Islam (2008), who also mentioned SMS technology as one of the promising means of creating a virtual interactive classroom in distance learning. The study focuses on the efficacy and feasibility of virtual classroom by means of integrating perceived broadcast video and SMS technology

On the other hand, findings of some recent studies suggested inconsistency. For example, in the study of Stockwell (2007), exploring the mobile-based intelligent vocabulary learning system, learners completed vocabulary activities through learning system. Learners completed vocabulary activities through either their mobile phones or personal computers. The findings of the study revealed that students preferred and performed better on computer than mobile phones in vocabulary learning. Again, MLU (2008) has explored the effectiveness of SMS vocabulary lessons of limited lexical information on the small screen of mobile phones. His result indicated that, although students had positive attitude towards learning vocabulary, technological limitations, unfamiliar presentations and learning activities prevented students from reading SMS lesson. Similarly, in a year-long pilot study conducted by Okunbor and Retta (2008) to investigate the use of mobile phones to enhance student learning, students were able to manage their academic and social lives using customized packages of applications developed by the wireless company for university students and made available to students on the national mobile phone network. The results of the study revealed that most of the students using the mobile-based applications found them insignificant. 
The conflicting findings show that the effectiveness of SMS for learning language needs further exploration and that more empirical studies are needed. Furthermore, such studies are rare in the context of Bangladesh, though few studies are carried out in other countries of the world. In this respect, the present study was design to examine the efficacy of SMS as a means of learning English specifically and efficacy of cell phone as language learning tool for undergraduate students of Bangladesh generally. Moreover, the study aimed to examine

1) What is the present status of undergraduate EFL classroom of Bangladesh?

2) To what extent do the students use cell phone for learning English?

3) What are the benefits and challenges of using SMS based lessons for learning English?

\section{Methodology}

\subsection{Participants}

One hundred EFL students of Jahangirnagar University, a public university of Bangladesh, participated in the study. All the students were first year undergraduate students of English Department of the University. The students had common features like having Bengali as their mother tongue, English as foreign language and everyone was Bangladeshi by birth. The age of the students ranged from 16-19. Five teachers of the English Departments of the same university also helped the study. Among the five teachers three teachers taught English literature and the other two taught English Linguistics. All the teachers had six years experience in teaching.

\subsection{Instruments}

To investigate the research questions three data collection instruments were applied: questionnaires for students, teachers' interview and classroom observation. The questionnaire for the students was divided into 4 parts. The first part included questions regarding the present status of EFL classroom of Bangladesh; the second part included questions regarding students cell phone use in the classroom; the third part includes questions regarding the frequency of cell phone use and the frequency of use those features for learning English; and the final parts include questions about the efficacy of cell phones as instructional tools. The teachers' interview was conducted to know about their opinions regarding the cell phone use in classroom, and about benefits and challenges of cell phone as language teaching tools in the EFL classroom. The students' questionnaire and questions of teacher interviews are attached in the 'Appendix' (1) and (2).

\subsection{Data collection and procedure}

For the study, five SMS-based EFL class tests were arranged by the author with the help of the teachers and students of English Department of Jahangirnagar University. In the SMS-based class tests we try to find out how much the SMS-based 'appropriate prepositions' lessons can help students in learning English preposition use at the same time eliciting the benefits and challenges of using cell phones in the EFL class room. In this study the researcher use only a handset Nokia-1100 without any help of web, laptop and multimedia projectors. Considering the frequent load shedding in Bangladesh the researcher did not use any electronic devices except mobile phones. It was a better opportunity for the author to observe the SMS based classroom very easily as she was a student of that University and also participated in the classroom as a student. The teachers and students were asked to charge the battery of their cell phones properly so that they can participate the whole period of SMS -based class without any break. The teachers were requested to report on the classroom observation. Both the teachers and students were enthusiastic in helping the researcher.

At first, the teachers sent SMS containing lessons on appropriate use of preposition in the sentences to the students' cell phones. The students were asked to study the lessons on the mobile screen and prepared them for a test on the lessons. This process continued for one week .After one week, the teachers were requested to prepare test questions on the preposition use and sent the question to the students' cell phones via SMS in the classroom. The teachers gave 20 multiple choice questions to the students in each SMS-based class and fixed 45 minutes to answer by means of sending messages to the teachers' cell phones. The teachers later provide feedback to the students through sending SMS. The multiple choice questions teachers assigned for test are like the following.

1) Why do you hang ( ) the examination hall?
a) In
b) at
c) on
d) around

2) The boy ran ( ) from home to join the army.
a) Around
b) away
c) about
d) off

3) Trees put ( ) new leaves in spring
a) Forth
b) down
c) down
d) on 
The whole process took 2 hours to be completed. The researcher collected the classroom observation reports from the teachers for further analyses. Then the researchers offered launch to the research participants and after taking launch the students were asked to fill-up the questionnaire and the teachers were also asked to express their opinion regarding the SMS-based class. Then the teachers' interviews were conducted in an informal environment where all the teachers were together in the teachers' lounge and the researchers requested them to give more 20 minutes for her research. The interview questions included the teachers' purpose of using mobile, their opinion regarding the cell phone practice in the classroom, and about the benefits and challenges of cell phone use in the EFL classroom of Bangladesh. The researcher recorded the whole interview session in her mobile phone recorder for the data analysis.

\section{Data analysis and discussion}

From the analysis of the received data the following issues can be identified.

\subsection{The present status of undergraduate EFL classroom in Bangladesh}

The present condition of English proficiency and efficiency of the undergraduate students is disheartening. A number of EFL students receive EFL instruction from the elementary level, but after completing their graduation students feel difficulty in using the language for communication and for real life situation. The language learning materials are still tedious and out-of-date. Students have to deal with a huge number of text books which include novels, fictions, and articles without any interest in English. Actually, the traditional teaching materials are too much paper-based without any technical support to motivate students for learning English. Very few teachers use multimedia in classroom and frequent load shedding also disrupts the multimedia use during class hours. The classroom condition is not interactive at all. Because in the large classes with about 80-110 students, teachers only deliver lectures either from textbooks or from their self designed notes. The teachers feel frustrated as the students don't response spontaneously in the classroom, even if they enforce the students to respond. Again, if the students respond their responses are very often incorrect and full of mistakes. Their speaking is poor as they only practise English in class but outside the classroom they have little exposure to English. The students, in fact, feel learning English as burdensome and boring. As a result, students show poor performance and proficiency in English at the undergraduate level.

\subsection{The use of cell phone in the EFL classrooms in Bangladesh}

From the evaluation of students' questionnaires it is learned that almost all the students participated in the present study owned a mobile phone except $5 \%$ female students who considered use of mobile phone as a disturbing factor (social abuse) for them. More than $60 \%$ students were acquainted with all the functions of their cell phones. They used their personal cell phone mostly for communicating with their parents, friends and teachers. But they hardly applied this technology for learning language. Students were asked question regarding their mobile use during class hours, and it is revealed that, they have to keep the ringtone during class hours. From time to time, the students were not even allowed for carrying their mobile phone with them during class time. Interview with the teachers also demonstrated that the teachers also themselves keep the ringtone silent during class time and students too are not allowed to use their cell phones or on the ring tone of cell phones during class time. Yet, abandoning the class rules some students used to play games or SMS during the class hours. They reported that students were too much addicted to use mobile phones now-a-days. In answer of the causes for their disallowing students in using mobile phones they mainly explain 2 causes:

1) Cell phones are distractions in class as the ring tone may divert the students' attention from class.

2) Students may misuse the cell phones or cheat if they are allowed to use mobile in the classroom.

The teachers also mention that the cell phones are now a fashion of the students and their uses are so much ingrained in students that banning their use from classroom is a hassle for the teachers.

\subsection{Frequency of students' cell phone use}

To measure the frequency of students cell phone practice students' responses were partitioned into three categories; often, sometimes and never (see part 3, Appendix 1). Part-3 of the questionnaire was directed to elicit the extent of students' cell phone use for usual practice and for learning English. Extensively, usual practice included communication with parents, teachers and friends and learning English included practicing reading, writing, listening and speaking. Twelve questions were asked to measure how frequent were students in using their cell phone features like SMS, games, audio, camera, Internet and recorder both for usual practice and for learning English. Figure $1 \&$ Figure 2 reveals the frequency of students' cell phone usages for usual purpose and for learning English respectively. Figure 1 reveals that SMS was the most frequently used cell phone function of the students for usual practice. All the students mentioned they often use SMS functions for communication and reported recorder as the least use functions for normal communication. Only 55\% students sometimes used recorder for personal 
activities. We find a relatively greater use of Games option which was often used by $50 \%$ students. Students' questionnaires also revealed they used the other features audio, camera, Internet occasionally (sometimes). Whereas students use SMS, Games frequently (often) for communication, no students were found using these two devices often for learning English (see Figure 2). Figure 2 demonstrates the low frequency of use of cell phone functions for learning English with a relatively higher uses of recorder and Internet which were used often only by $10 \%$ and $12 \%$ students respectively. Other devices like audio and camera were never used cell phone functions for learning English; only a small number of students used these functions occasionally. In summary, it can be stated that students used various cell phone features to a great extent for usual practice but they were not used to apply those for learning English.

\subsection{The benefits and challenges of cell phones use as instructional tools for teaching and learning English}

\subsubsection{Benefits}

- Cell phones are ubiquitous and easily portable. For this, the students can start using cell phones in the classroom and as they need no space management students can even keep it in their pocket. Unlike computers they can keep it anywhere and anytime.

- $\quad$ From the SMS-based class it is also observed that students feel more free and easy to answer the questions via mobile devices instead of face to face class.

- It can also help students by giving them chance to follow their own progress and promote their learning

- It also improves students engagement by offering a more relaxed and comfortable setting for learning

- Create enjoyable classroom and remove the boredom of traditional classroom practice in language teaching.

- It can ensure the participation of all students in the classroom that was experienced from the previous SMS based classroom instruction.

- It will be helpful for the students who feel shy to expose their problems and can ensure the feedback to all students.

- It is cost saving as the call rate and SMS rate are very cheap. Poor students can also afford and maintain a mobile phone.

- It will help to promote an interactive classroom.

- It will also promote a virtual classroom without the panic of electricity supply.

- It will be easy and pervasive as students know the functions of their mobile phones and able to carry everywhere.

- Moreover the mobile can be an effective language learning tool in the classroom other than PCs through the use of sophisticated Internet function.

- $\quad$ More specifically, wireless mobile learning devices can offer amazing technical capabilities to develop new ways for language learning in Bangladesh as it needs only skilled management with low cost.

- Enable students to access lessons anywhere and anytime using common mobile communication devices.

- $\quad$ Significant progress in language learning can be possible by creating a mobile learning environment by utilizing the cell phone features.

- Learners can immerse in verbal learning being provided from uniform access medium.

4.4.2 Challenges

- Students are not allowed to use mobile phone in the classroom.

- Cell phones cannot accommodate the traditional contents of language learning due to the limitations of screen size. Therefore, for cell phone display teachers have to design new lessons which are expensive to manage.

- Battery charge is another problematic factor.

- The teachers have no training to arrange m-learning activities through cell phones in the classroom.

- Cost for arranging language learning activities via sending SMS and data transmission.

- Students do not feel comfortable in typing on the tiny keyboard of mobile phones.

- $\quad$ Not enough screen size to read the SMS. 
- Word limitation is another inhibiting factor. Generally, the length of SMS in a normal mobile phone is 160 characters.

- The teachers mention that it doesn't have enough space storage like computer. Plenty of documents cannot be stored at a time.

- The teachers express their discomfort in managing the students with cell phones and they mentioned that extra control and care will be required to prepare a language class by using cell phones.

\section{Recommendations}

Therefore, some probable solutions of the prevailing problems are here suggested:

\section{Mobile cost solutions}

To establish cell phones as language learning tools the first problem is cost of SMS, call or data transmission. Students are unwilling to spend extra money for sending SMS. The probable solution of this problem may be that the University authority with the help of a mobile phone company may cut down the cost and assert the good quality of both sending and receiving text SMS. The SMS system can be used to provide administrative information and exam date fixation and postponement.

\section{Screen size solution}

Screen size was another problem that students commented upon their SMS based classroom. But the recent i phone or new brand of cell phones are designed with big screen size and clear monitor. Sony Ericson P990i had a large screen size and alphabetical keyboard to facilitate the writing text message (Pouezevara \& Khan, 2007). Programmers and designers of mobile phones can take initiatives to bring forward new models of cell phones so that the students demand can be fulfilled. They should also update functions of cell phones and improve the suitable software for the new applications for language teaching and learning to facilitate teachers and students.

\section{Keyboard solution}

One more problem that most of the students faced while typing SMS was the miniature keyboard of cell phones. Actually the keyboard features of cell phones are not for typing text rather for typing digits or numbers. A cell phone keyboard has 12 keys for 0-9.Additionally, word limitations of each message that is maximum 160 characters creates problem in typing longer message. Some attempts have been made in the past to improve the physical design of the keyboard, but these do not seem to be able to rival the standard design in terms of popularity (Sorensen, 2007). But recently i-phone innovation designs new mobile phones with large screen and keyboard. We can expect within few years we will get handsets with more improvised and updated keyboards.

Change in social value and implementing rules for mobile use in the classroom

To use mobile phones as instructional tools our views and beliefs about mobile as distractions and disruptions should be changed. Teachers should allow students use their favorite technology to use in classroom in regards that a ban on mobile devices would thwart innovations in schools as the very tools have the potential to motivate learners, individualize learning, add to the options that teachers can employ for immediate assessment of group learning in the classroom and in general prepare youth for the competitive global society of which they are parts (Deubel, 2009). To avoid distractions and students cheating concrete rules should be assigned and implemented to use the tools in the classrooms. Mobile technologies should be integrated into units of lessons and study to promote further development in teaching and learning EFL. Therefore, educational institutions need an instructional model that will help faculty instruction implementers to create and maintain content and learning activities that will be delivered to their student population

\section{Providing teachers' training}

Teachers discomfort in managing classroom activities is another inhibiting factor, for which teachers should be provided with proper training and instruction. If they can be habituated in handling the issues associated with cell phone functions they feel more comfortable and easy to manage the classroom. Again, to design new and creative functions by mobile devices teachers have to know the new technology and software use. For this, the government should enhance training for university teachers. Students are now aware of modern technology and devices, so, it is not so difficult for them to perceive the mobile devices. The teachers may help by giving proper instructions of using the devices in the classroom and ensure success.

\section{Solutions of battery charge}

The students explained the limited battery charge as a disturbing factor. Students can charge the battery before joining the cell phone learning activities. In this case, teachers or instructors should fix the time limit and give 
students chance to recharge the battery. Many cell phones in Bangladesh can be run by solar energy or light-weight generators (Mahmud, 2006). In this case, with cooperation with telecommunication companies universities can provide students with cell phones of low price and charged with solar energy.

\section{Updated policy}

To integrate cell phones in educational institutions a planned and updated policy should be established as to avoid the difficulty of promotion of cell phone integrated classroom. Curriculum and syllabus should include mobile assisted language learning (Mall).The university authority should allocated proper financial support to promote the integration of cell phones in the language teaching activities.

\section{Conclusions}

To meet the demand for 21 st century technological advancement is a must for educational institutions. Among the developing countries mobile technologies are developing comparatively rapidly in Bangladesh, whereas, the country has lagged behind using other technologies. Handheld devices are now used for learning in countries like U.S.A, Japan, U.K, Korea and even in many developing countries Taiwan, Singapore, and India (Deubel, 2009). So we need to make good use of this by developing cell phones as educational tools. Here, the universities can be a more suitable place to introduce students to the ways that they can use their personal mobile devices to support learning facilities to a greater extent, as almost all the students possess cell phones and know the use of the mobile devices. Considering the large number of mobile phone users and the potential for mobile devices for learning English proper policy should be developed to integrate mobile technologies in study units and lessons. Further researches are required to design proper methods to use cell phones as instructional tools. Marc Prensky (2005) wondered why we are fighting the trend toward using cell phones in education. He maintained that students can learn anything from a cell phone but among the most frequent, time-taste, and effective of these are listening, observing, imitating, questioning, reflecting, trying, estimating, predicting, speculating and practicing. So we should adopt all the potential functions and capacities of cell phones for language teaching and learning and offer the learners more effective ways for practice English by using the cell phone devices.

\section{References}

Alam, M.S. \& Islam, Y. M. (2008). Virtual Interactive Classroom (VIC) using Mobile Technology at the Bangladesh Open University (BOU).Retrieved from http://wikieducator.org/images/4/45/PID_563.pdf.

Chen, C. \& Chung, C. (2007).Personalized mobile English vocabulary learning. Computers \& Education, 51(2), 624-647.

Chen, Y. (2007). Extending Family to School Life: College Students' Use of Mobile Phone. Paper presented at the annual meeting of the International Communication Association, TBA, San Francisco, CA.

Chinnery, G. M. (2006). Emerging Technologies Going to the MALL: Mobile Assisted Language Learning. Language Learning \& Technology, 10 (1), 9-16

Cui, G. \& Wang, S. (2008). Adopting Cell Phones in EFL Teaching and Learning. Journal of Educational Technology Development and Exchange, 1 (1), 68-80.

Deubel, P. (2009) Mobile Devices: Facing challenges and opportunities for learning. THE journal. Retrieved from http://thejournal.com/articles/2009/03/19/mobile-devices-facing-challenges-and-opportunities-for-learning.aspx.

Klopfer, E, Squire, K and Jenkins, H. (2002). Environmental Detectives: PDAs as a window into a virtual simulated world. Proceedings of IEEE International Workshop on Wireless and Mobile Technologies in Education. Vaxjo, Sweden: IEEE Computer Society, 95-98.

Kukulska-Hulme, A. (2006). Mobile language learning now and in the future. In: Svensson, Patrik ed. Fro an vision till praktik: Spr ${ }^{\circ}$ akutbildning och Informationsteknik (From vision to practice: language learning and IT). Swedish Net University (N"atuniversitetet), Sweden, pp. 295-310.

Kukulska- Hulme, A. \& Shield, L. (2008). An overview of mobile assisted language learning: From content delivery to supported collaboration and interaction: Recall 20(3), 271-289.

Li, Chun.(2009).SMS-based vocabulary learning for ESL students( MCIS thesis). Retrieved from http://repositoryaut.lconz.ac.nz/bitstream/10292/746/5/LiC_a.pdf.

Lu, M. (2008). Effectiveness of vocabulary learning via mobile phone. Journal of Computer Assisted Learning, 24(6), $515-525$.

Mahmud, A. (2006). Shidhulai Swanirvar Sangstha: Bringing Information Technology to Rural Bangladesh by Boat. Council on Library and Information Resources. Washington, D.C. 
Markett, C., Sanchet, I.A., Weber, S. \& Tangney, B. (2006). Using Short Message Service to encourage interactivity in the class room. Computers \& Education, 46(3), 280-293.

Meurant, R C. (2007).Using Cell phones and SMS in second language pedagogy: A review with implications for their intentional use in the L2 classroom. Journal of Convergence Information Technology, 2 (1), 98-106.

Okunbor, D \& Retta, G. (2008). Analysis of a mobile learning pilot study. Math and Computer Science, [Online].Retrieved March, 04.2009. Available: http://digitalcommons.uncfsu.edu/macsc wp/2.

Prensky, M. (2004). What can you learn from a cell phone? Almost anything. Retrieved March 3, 2008 from http://www.marcprensky.com/writing/Prensky-What_Can_You_Learn_From_a_Cell_Phone-FINAL.pdf

Prensky, M. (2005). What can you learn from a cell phone? Almost anything! Innovate Journal of Online Education, 1 (5). Retrieved from http://www.innovateonline.info/index.php?view=article\&id=83.

Pouezevara, S. L., \& Khan, R. (2007). Learning communities enabled by mobile technology: A case study of school-based, in-service secondary teacher training in rural Bangladesh. In Innovative information and communication technology in education and its potential for reducing poverty in the Asia and Pacific region $\begin{array}{llllll}\text { (Appendix 11). Asian } & \text { Development } & \text { Bank. } & \text { Retrieved } & \text { from }\end{array}$ http://www.adb.org/Documents/Reports/consultant/39035-REG/appendix11.pdf.

Power, T. and Shrestha, P. (2009). Is there a role for mobile technologies in open and distance language learning? An exploration in the context of Bangladesh. In: 8th International Language and Development Conference, 23-25 June 2009, Dhaka, Bangladesh.

Sorensen, K. (2005). Multi-objective optimization of mobile phone key maps for typing messages using a word list. European Journal of Operational Research, 179(2007), 838-846.

Song, Y. \& Fox, R. (2005). Integrating m-technology into web-based ESL vocabulary learning for working adult learners. Proceedings of the 2nd IEEE international workshop on wireless and mobile technologies education. Jhongli, Taiwan, IEEE Computer Society.

So, S. (2009). The development of a SMS-based teaching and learning system. Journal of Educational Technology Development and Exchange, 2(1), 113-124.

Stockwell, G. (2007). Vocabulary on the move: Investigating an intelligent mobile phone-based vocabulary tutor. Computer Assisted Language Learning, 4,365-383

Thornton, P. \& Houser, C. (2005). Using mobile phones in English education in Japan. Journal of computer assisted learning, 21(3), 217-228.

\section{Appendix-1}

\section{Questionnaire for students}

Name of the student.......... Gender: Male/Female, Age.....Study area: English literature/English linguistics

\section{Part-1}

1. Do you feel English language still difficult? Yes/no

2. Do you feel interested in your language class? Yes/ No

3. You response in the classroom: Often/ seldom/Never

4. The technical support in your classroom: Sufficient/ meet the demand/ insufficient

5. Your teachers use the language teaching materials Technology-based/Paper-based

6. Your language learning materials are: Interesting/ tedious

7. Your language learning materials are: Modern /out of date

8. Your teachers use multimedia in the classroom: Often/ Seldom/Never

9. Do you feel the English lessons interesting? Yes/No

10. Do you think your English language classes are interactive? Yes/No

\section{Part-2}

1. Do you use mobile? Yes/No

2. Which one you think to be easier to operate? Mobile / computer

3. Do your teachers permit you to use your cell phones in class? Yes/No 
4. Start writing your option according to importance. Most of the time you use mobile phone to contact with your family / to contact with friends/to contact the teachers/ to learn English.

5. You know the functions of your cell phones more than $90 \% /$ more than $50 \% /$ more than $10 \%$.

\section{Part -3}

7. You send SMS from your mobile: Often/ Sometimes /Never

8. You do SMS for learning English: Often/ sometimes/ never

9. You play mobile games: Often/ sometimes/ never

10. You play word games for learning spelling: Often/ sometimes/ never

11. You listen to your mobile audio: Often/ sometimes/ never

12. You listen to mobile audio for listening: music/ news/ English lessons

13. You use mobile camera: Often/ sometimes/ never

14. You use your mobile camera for learning language: often/ seldom/ never

15. You browse web Internet: often/ sometimes/ never

16. You browse web for searching English language learning materials: Often/ sometimes/ Never

17. You use the voice recorder of your mobile phone: often/ sometimes/never

18. You use the voice recorder for practicing English language: sometimes/never

\section{Part-4}

1. You prefer to read mobile message/ Email message on PCs

2. Do you feel comfortable in reading SMS questions on mobile screen? Yes/ No

3. Do you think it is easy to type in mobile phone keyboard? Yes / No

4. Do you think answering SMS questions is more comfortable than face to face answers in class? Yes /No

5) Do you consider receiving feedback from teachers via mobile SMS is more effective than traditional way of receiving feedback? Yes/No

6. Do you enjoy the SMS-based classroom tests? Yes/No

7. Do you consider SMS-based instruction helps you to assess your own performance? Yes/No

8. Do you think SMS cost is a problematic factor? Yes, it is tough /no, I can afford easily.

9. Do you think battery life is a problematic factor? Yes /No

10. You consider use of cell phones in the EFL classroom as a pedagogical tool-effective/partly effective/ineffective

11. Write about the benefits and challenges of using cell phones as language learning tools in the

EFL classroom.

\section{Appendix-2}

\section{Teachers' Interview}

Full name.

Teaching experience.

1. Do you use mobile? What are the purposes of your using mobile?

2. What is the present status of undergraduate EFL classroom in Bangladesh?

3. What are the problematic factors you think to create an interactive EFL classroom?

4. Do you allow your students in using cell phones in the classroom? If the answer is 'no', please explain the reasons.

5. Do you think that mobile can be a useful tool for language learning? Please show reason for your answer.

6. What are the benefits and challenges in using cell phones as language learning tools in the EFL classroom of Bangladesh? 


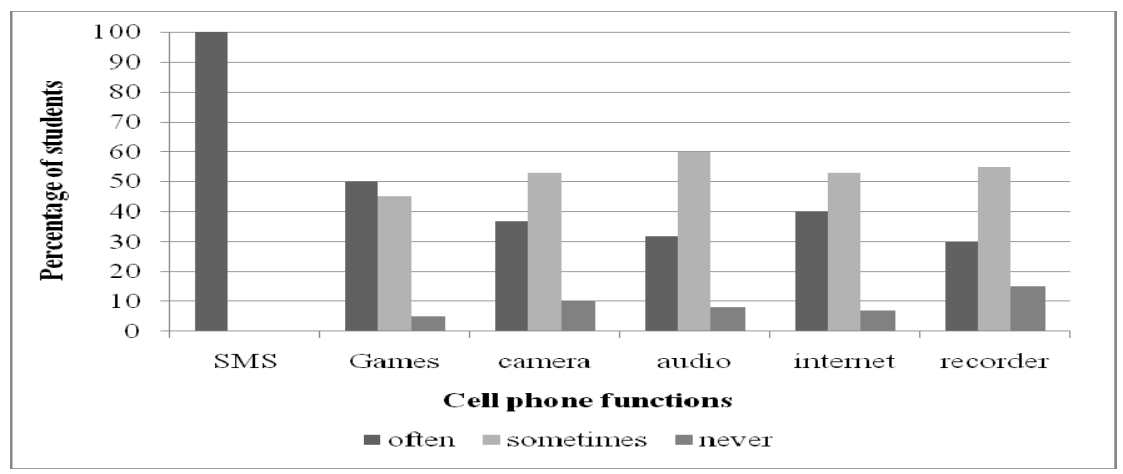

Figure 1. Frequency of students' cell phone usages for usual practice

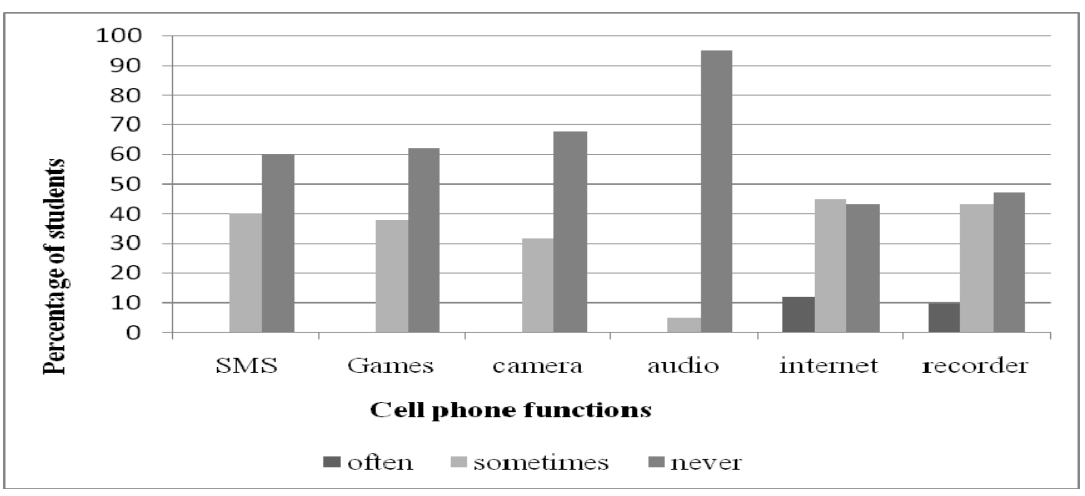

Figure 2. Frequency of students' cell phone usages for learning English 